\title{
WATER ADSORPTION ISOTHERMS AND ISOSTERIC SORPTION HEAT OF SPRAY-DRIED AND FREEZE-DRIED DEHYDRATED PASSION FRUIT PULP WITH ADDITIVES AND SKIMMED MILK
}

\author{
Isotermas de adsorção e calor isostérico de sorção de polpa de maracujá \\ desidratada por spray dryer e liofilizador com aditivos e leite desnatado
}

\author{
Kelly Tafari Catelam¹, Carmen Sílvia Fávaro Trindade², Javier Telis Romero ${ }^{3}$
}

\begin{abstract}
Moisture equilibrium data of passion fruit pulp powders with maltodextrin and gum arabic were obtained by two different drying methods (spray drying and freeze drying) and determined at $20,30,40$ and $50^{\circ} \mathrm{C}$. Skimmed milk was used to substitute part of these additives in the samples. One formulation using passion fruit pulp/maltodextrin/skimmed milk (PMS) was prepared, and another using passion fruit pulp/gum arabic/skimmed milk (PGS). The behavior of curves was type III, according to Brunauer's classification. GAB models were fitted to experimental equilibrium data. The parameters obtained from GAB models was affected by the presence of additives. The behavior of the sorption isotherms for different temperatures are similar, noting only a small effect of temperature. There were little differences between both drying methods and additives used in relation to equilibrium moisture content. The parameters obtained with the addition of the skimmed milk were considered satisfactory (Xm values ranged from 0,04084 to 0,06488 in dry basis), demonstrating that it is an effective and cheap alternative for regular additives. A progressive increase in the heat of sorption in relation to decreasing moisture content was observed and the heat of sorption values of different samples are all similar, comparing the relative equilibrium moisture content.
\end{abstract}

Index terms: Maltodextrin, gum arabic, GAB model.

\section{RESUMO}

Dados de umidade de equilíbrio da polpa de maracujá em pó com maltodextrina e goma arábica obtidas por dois diferentes processos de secagem (spray dryer e liofilizador) foram determinados a 20, 30, 40 e $50^{\circ} \mathrm{C}$. Leite desnatado foi utilizado nas amostras em substituição a uma parte desses dois aditivos. Prepararou-se uma formulação, usando polpa de maracujá/maltodextrina/leite desnatado (PMS) e outra com polpa de maracujá/goma arábica/leite desnatado (PGS). Os comportamentos das isotermas obedeceram ao tipo III, de acordo com a classificação de Brunauer e utilizou-se o modelo de GAB para ajuste dos dados de equilíbrio. Os parâmetros obtidos pelo modelo de GAB foram afetados pela presença dos aditivos. O comportamento das isotermas de sorção para as diferentes temperaturas foram similares, notando-se uma pequena diferença em relação ao efeito da temperatura. Observaram-se também pequenas diferenças entre os dois métodos de secagem utilizados e os aditivos usados em relação ao teor de umidade de equilíbrio. Os parâmetros obtidos pela adição do leite desnatado foram considerados satisfatórios $\left(X_{m}\right.$ variando de 0,04084 a 0,06488 em base seca) mostrando que o leite desnatado pode ser uma alternativa boa e com menor custo na substituição dos aditivos comumente utilizados nesse tipo de processo. Observou-se uma aumento do calor isostérico de sorção em relação a diminuição do teor de umidade e os valores das diferentes amostras utilizadas foram similares, comparando-se o teor de umidade de equilíbrio.

Termos para indexação: Maltodextrina, goma arábica, modelo de GAB.

(Received in june 30, 2011 and approved in september 22, 2011)

\section{INTRODUCTION}

In general, fresh fruits have a high moisture content and are therefore very perishable, with a limited shelf life. In order to prolong shelf life, processing and preservation methods, such as the drying of fruit pieces or preparation of fruit juice, may be used. The drying of fruit juice produces a stable, easily-handled form of the juice that can be reconstituted rapidly to a good quality product resembling the original juice as closely as possible. The drying of fruit juices and other products with high sugar content presents technical difficulties because of their hygroscopicity and thermoplasticity at high temperatures and humidities (ADHIKARI et al., 2004). For this reason, the addition of maltodextrin and gums as well as other substances such as pectins, calcium silicate, and carboxy-methyl cellulose, has been used in the production of powder juices (BHANDARI et al., 1993).

Skimmed milk presents non-stick properties similar to other commonly used additives (ADHIKARI et al., 2004).

\footnotetext{
${ }^{1}$ Universidade Estadual Paulista/UNESP - Departamento de Engenharia e Tecnologia de Alimentos - Rua Cristovão Colombo - n. 2265 - Jardim Nazareth 15054-000 - São José do Rio Preto - SP - Brasil - kelly tfcl@yahoo.com.br

2Universidade de São Paulo/USP - Faculdade de Zootecnia e Engenharia de Alimentos - Pirassununga - SP - Brasi

${ }^{3}$ Universidade Estadual Paulista/UNESP - Departamento de Engenharia e Tecnologia de Alimentos - São José do Rio Preto - SP - Brasil
}

Ciênc. agrotec., Lavras, v. 35, n. 6, p. 1196-1203, nov./dez., 2011 
Besides, compared to gum arabic, skimmed milk is highly available in the most countries. According to Langrish et al 2007, in a study of spraying maltodextrin and skimmed milk, both had the same rates of cohesion and adhesion, however, maltodextrin (DE 18) showed a lower deposition rate than milk and particularly a lower adherence rate than the subsequent particle cohesion between them after the initial period of drying. The lowest rates of deposition of maltodextrin were associated with its higher glass transition temperature compared to skimmed milk. Therefore, skimmed milk could be useful to substitute part of other regular additives.

Moisture sorption isotherms describe the relationship between water activity and the equilibrium moisture content of a food product. Knowledge of water sorption isotherms and of net isosteric heat of sorption is of great importance to various food processes, including drying, storage and packaging. They are useful to calculate time and energy consumptions during drying, to predict ingredient behavior upon mixing, to assist packaging selection, to model moisture changes during storage and to predict the shelf life of food products (LOMAURO et al., 1985; SIRIPATRAWAN; JANTAWAT, 2006; COMUNIAN et al. 2011). These properties also give information about sorption mechanisms and interactions between food components and water (GABAS et al., 2000). The GAB equation is recommended to describe passion fruit pulp isotherms, since it has been extensively used for foodstuffs, especially for fruits (LOMAURO et al., 1985; GABAS et al., 2000; TELIS et al., 2000), as well as being a simple means of supplying parameters with physical meaning.

The aim of this study was to determine the influence of different compositions of additives and drying methods on sorption isotherm data for passion fruit pulp and also the isosteric heat of adsorption.

\section{MATERIALS AND METHODS}

\section{Raw material}

Samples of passion fruit (Passiflora edulis fo. flavicarpa $\mathrm{O}$. Deg.) with soluble a solid content of $11.7^{\circ}$ Brix, and moisture content of $85 \%$ (wet basis) were obtained at the local market (São José do Rio Preto, SP, Brazil). Solutions were prepared using passion fruit pulp, maltodextrin DE 10 (MOR-REX ${ }^{\circledR}$ Corn Products, Brazil) and skimmed milk (Commercial UHT skimmed milk, Batavo ${ }^{\circledR}$, Brazil) (PMS) or using passion fruit pulp, gum arabic (Synth, Brazil) and skimmed milk (PGS). Proportions of solutions, in dry basis, between passion fruit pulp:maltodextrin or gum arabic:skimmed milk were 1:4:4 and 1:2:6 to samples using maltodextrin and gum arabic, respectively. These proportions had been chosen according to good yields obtained by preliminary tests in spray drying of passion fruit pulp by varying these additives and their ratios.

\section{Drying methods}

The spray drying process was performed in a laboratory scale spray dryer MSD 1.0 (Labmaq do Brazil Ltda, Ribeirão Preto, Brazil). The mixture was kept under magnetic agitation, at room temperature, being fed into the main chamber through a peristaltic pump, with drying air flow rate of $30 \mathrm{~L} / \mathrm{h}$. A feed flow rate of $0.4 \mathrm{~L} / \mathrm{h}$ was used, the inlet air temperature was $120^{\circ} \mathrm{C}$ and the outlet air temperature was around $90^{\circ} \mathrm{C}$. The freeze drying process was performed in a laboratory scale freeze dryer L101 (Liobrás, São Carlos, Brazil). The samples were put in stainless steel trays and storage at $-29^{\circ} \mathrm{C}$ in a freezer for $48 \mathrm{~h}$. After that the trays were put in the freeze dryer during $24 \mathrm{~h}$ in a vacuum chamber (pressure of $300 \mu \mathrm{mHg}$ ) and $-40^{\circ} \mathrm{C}$.

\section{Sorption isotherms}

Equilibrium moisture content of pulp powder at ten water activities were determined by the static gravimetric method (JOWITT et al., 1983) at 20, 30, 40 and $50^{\circ} \mathrm{C}$. Ten saturated salt solutions $\left(\mathrm{NaOH}, \mathrm{LiCl}, \mathrm{KC}_{2} \mathrm{H}_{3} \mathrm{O}_{2}, \mathrm{MgCl}_{2}\right.$, $\left.\mathrm{K}_{2} \mathrm{CO}_{3}, \mathrm{Mg}\left(\mathrm{NO}_{3}\right)_{2}, \mathrm{NaNO}_{2}, \mathrm{NaCl}, \mathrm{KCl}, \mathrm{BaCl}_{2}\right)$ were prepared corresponding to a range of water activities from 0.059 to 0.907 (RAHMAN, 1995). Triplicate samples of around $1 \mathrm{~g}$ of passion fruit powder were weighed into small plastic receptacles and placed on tripods in jars, which were then tightly closed and placed in a temperature-controlled chamber $\left(20,30,40\right.$ and $\left.50^{\circ} \mathrm{C}\right)$. The required equilibration time was 4 to 5 weeks, based on the change in sample weight expressed on a dry basis, which did not exceed $0.1 \%$ (0.001 g/g dry solids).

\section{Mathematical development}

GAB is a relatively simple model with a small number of parameters, which have a physical meaning, and can be applied to a large range of water activities. It is mathematically expressed as shown in equation (1) (VAN DEN BERG, 1985). The parameters were estimated by fitting the mathematical model to the experimental data using nonlinear regression.

$$
X_{e q}=\frac{(C-1) \mathrm{Ka}_{\mathrm{w}} \mathrm{X}_{\mathrm{m}}}{1+(\mathrm{C}-1) \mathrm{Ka}_{\mathrm{w}}}+\frac{\mathrm{Ka}_{\mathrm{w}} \mathrm{X}_{\mathrm{m}}}{1-\mathrm{Ka}_{\mathrm{w}}}
$$


where: $\mathrm{X}_{\mathrm{eq}}$ is the equilibrium moisture content (dry basis), $\mathrm{X}_{\mathrm{m}}$ is the moisture content (dry basis) corresponding to an adsorbed monolayer (BET), $\mathrm{a}_{\mathrm{w}}$ is the water activity, and $\mathrm{C}$ and $\mathrm{K}$ are constants related to the temperature effect (equations 2 and 3).

$\mathrm{C}=\mathrm{C}_{\mathrm{o}} \exp \left(\frac{\Delta \mathrm{H}_{\mathrm{c}}}{\mathrm{RT}}\right)$

$\mathrm{K}=\mathrm{k}_{\mathrm{o}} \exp \left(\frac{\Delta \mathrm{H}_{\mathrm{k}}}{\mathrm{RT}}\right)$

where: $\mathrm{R}$ is the universal gas constant, $\mathrm{T}$ is the absolute temperature, $\Delta \mathrm{H}_{\mathrm{c}}$ and $\Delta \mathrm{H}_{\mathrm{k}}$ are functions of the heat of sorption of water $\Delta \mathrm{H}_{\mathrm{c}}=\mathrm{H}_{\mathrm{m}}-\mathrm{H}_{\mathrm{n}}$ and $\Delta \mathrm{H}_{\mathrm{k}}=\lambda-\mathrm{H}_{\mathrm{n}}$. In the above expressions $\mathrm{C}_{\mathrm{o}}$ and $\mathrm{k}_{\mathrm{o}}$ are adjusted constants for the temperature effect; $\mathrm{H}_{\mathrm{m}}$ and $\mathrm{H}_{\mathrm{n}}$ are the heat of sorption of the monolayer and the multilayer of water respectively.

The isosteric heat of sorption $\left(q_{\mathrm{st}}\right)$ is defined as the difference between the total heat of sorption $\left(Q_{\mathrm{st}}\right)$ and the heat of water vaporization. It can be determined from equation 2, which is derived from the Clausius-Clapeyron equation (RIZVI, 1995). The isosteric heat of sorption $\left(\mathrm{q}_{\mathrm{st}}\right)$ is a differential molar quantity derived from the temperature dependence of the isotherm. This approach assumes that the isosteric heat is invariant with temperature and the application of this method requires the measurement of sorption isotherms at more than two temperatures
(MCLAUGHLIN; MAGEE, 1998). The parameters in Equation (4) are: $\mathrm{q}_{\mathrm{st}}$ (isosteric heat of sorption), $\lambda$ (heat of condensation of pure water on limit temperature tested) $\mathrm{Q}_{\mathrm{st}}$ (total heat of sorption), $\mathrm{R}$ (universal gas constant), $\mathrm{T}$ (absolute temperature) and $\mathrm{X}$ (equilibrium moisture content).

$$
\left.\frac{\partial \ln \left(\mathrm{a}_{\mathrm{w}}\right)}{\partial(1 / \mathrm{T})}\right|_{\mathrm{X}}=-\frac{\mathrm{Q}_{\mathrm{st}}-\lambda}{\mathrm{R}}=-\frac{\mathrm{q}_{\mathrm{st}}}{\mathrm{R}}
$$

\section{RESULTSAND DISCUSSION}

\section{Sorption isotherms}

Figure 1 show experimental sorption isotherms for PMS powder obtained by spray drying at different temperatures with the respective fittings of the GAB model. It can be seen that the behavior of all curves was type III, according to Brunauer's classification (BRUNAUER et al., 1940). The behavior was similar to PMS samples obtained by freeze drying and PGS samples obtained by freeze and spray drying.

The equilibrium moisture content tended to decrease with increasing temperature in a given water activity, both for the samples obtained by spray drying and freeze-dried ones, as shown in Figure 1. The decrease in Xeq was due a reduction in the number of active sites due to chemical and physical changes induced by temperature. The extent of this decrease depends on the composition of foods (RIZVI, 1995). Pedro et al. (2010)

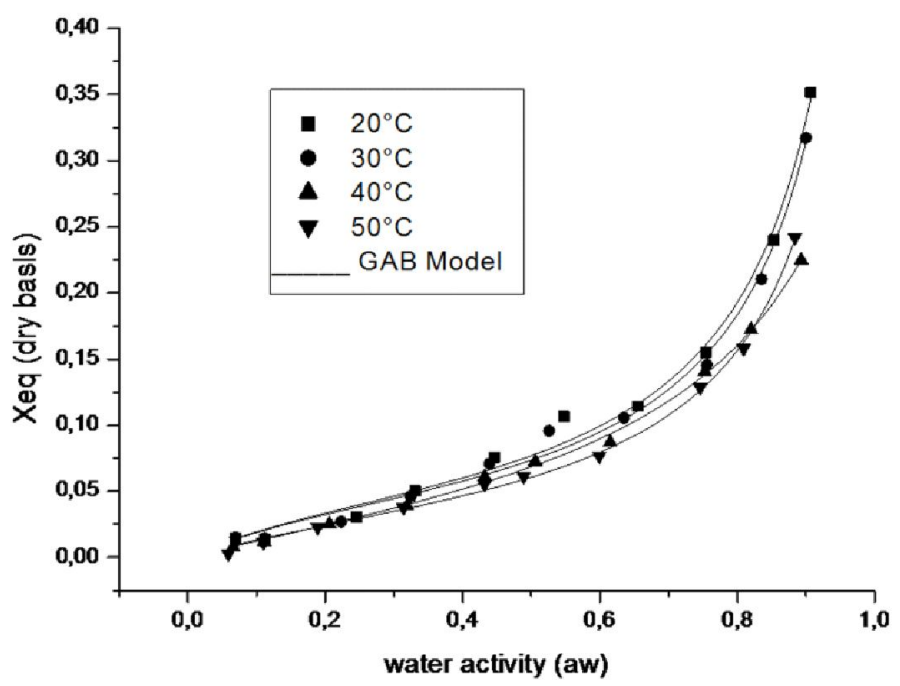

Figure 1 - Sorption isotherms of passion fruit pulp:maltodextrin:skimmed milk (PMS) powder samples at different temperatures obtained by spray dryer.

Ciênc. agrotec., Lavras, v. 35, n. 6, p. 1196-1203, nov./dez., 2011 
observed that temperature had a very pronounced effect on the values of equilibrium moisture sorption isotherms of the passion fruit pulp powder obtained by drying in vacuum oven. Hubinger et al. (1992) found that the isotherms of pineapple, mango and guava dried under vacuum, at temperatures of 25 and $50^{\circ} \mathrm{C}$, showed the same behavior observed by Pedro et al. (2010). Gabas et al. (2007) and Martinelli et al. (2007) observed no significant effect of temperature on the isotherms of pineapple powder and lemon powder, both with $18 \%$ maltodextrin obtained by vacuum drying.

Sorption isotherms showed an increase in equilibrium moisture content with increasing water activity (Figures 1 and 2). Similar trends in isotherms were observed for maltodextrin and gum arabic spray dried powders (GABAS et al., 2007; KUROZAWA et al., 2009; TONON et al., 2009; COMUNIAN et al., 2011).

Figure 2 shows a small difference between the equilibrium moisture content (Xeq) between the PMS and PGS samples atomized and lyophilized at $20^{\circ} \mathrm{C}$. The same behavior was observed for other temperatures (30, 40 and $50^{\circ} \mathrm{C}$ ) so we can report that the type of additive used did not influence considerably the values of equilibrium moisture sorption. These results are probably due to the similarity between the glass transition temperature of maltodextrin and gum arabic, around $10^{\circ} \mathrm{C}$ difference, according Collares et al. (2002). Gum arabic has Tg values greater than maltodextrins (COLLARES et al., 2004) so, is probably more effective to reduce the hygroscopicity of the powders. On the other hand, the high cost of gum arabic has motivated the search for substitute materials
(MCNAMEE et al., 1998). Maltodextrin is an additive commonly used because, besides its low cost, it has low hygroscopicity, prevents agglomeration of particles and has an antioxidant effect (REINECCIUS, 1991; SHAHIDI; HAN, 1993).

According to Pedro et al. (2010), although the isotherms of pure passion fruit pulp powder (PP) and additives have shown the same qualitative behavior, considerable differences in the values of equilibrium moisture content for the studied samples was noted. It was observed that the isotherms of the PP samples showed higher values of equilibrium moisture content than samples containing maltodextrin and gum arabic, for all temperatures studied. These results show that these additives cause changes in the hygroscopic behavior of dehydrated passion fruit pulp. The decrease in equilibrium moisture content in juices spray dried with additives reflected a reduction in the number of active sites able to link with water, that are ordinary in juices, as hydroxil groups of small carbohydrates. These groups were linked with the carrier or were immobilized by the carrier.

Comparing the PMS and PGS samples in the two drying methods used (spray and freeze drying), we observed that for both samples, the behavior of the curves of equilibrium moisture content versus water activity, as well as the values themselves of equilibrium moisture content, were very similar at $20^{\circ} \mathrm{C}$ (Figure 3 ), $30,40^{\circ} \mathrm{C}$ and $50^{\circ} \mathrm{C}$. Probably because the formulation used for both dehydration processes was similar, so the composition of the powders was similar.

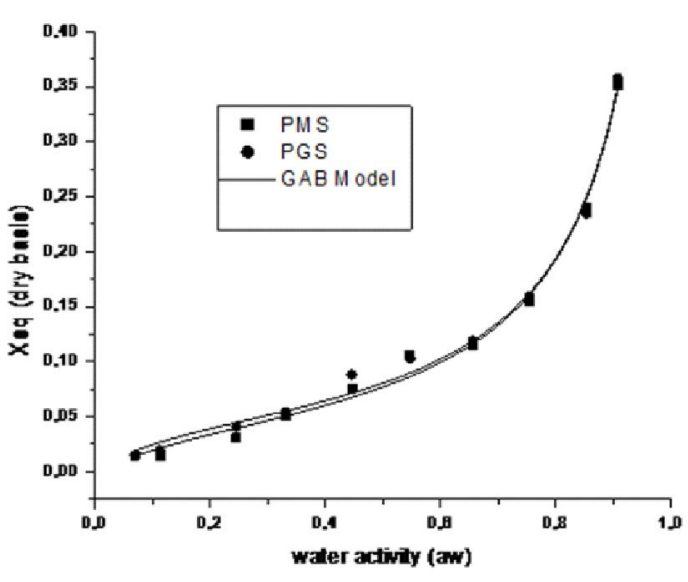

(a)



(b)

Figure 2 - Influence of additives on sorption isotherms of passion fruit pulp:maltodextrin:skimmed milk (PMS) and passion fruit pulp:gum arabic:skimmed milk (PGS) powder samples at $20^{\circ} \mathrm{C}$ obtained by (a) spray dryer and (b) freeze dryer. 
The results of nonlinear regression analysis to fitting mathematical GAB models to experimental data are shown in Table 1 for spray drying and freeze drying. The fitting of the isotherms with GAB model was high $\left(R^{2}>0.99\right)$. Parameter values of the GAB equation also show the similarity between this study using skimmed milk and the others such as Righetto and Netto (2005), Gabas et al. (2007), Martinelli et al. (2007) and Pedro et al. (2010), who used only the additives commonly found in the literature (maltodextrin and gum arabic), showing that skimmed milk can useful and cheap substitute for these additives.

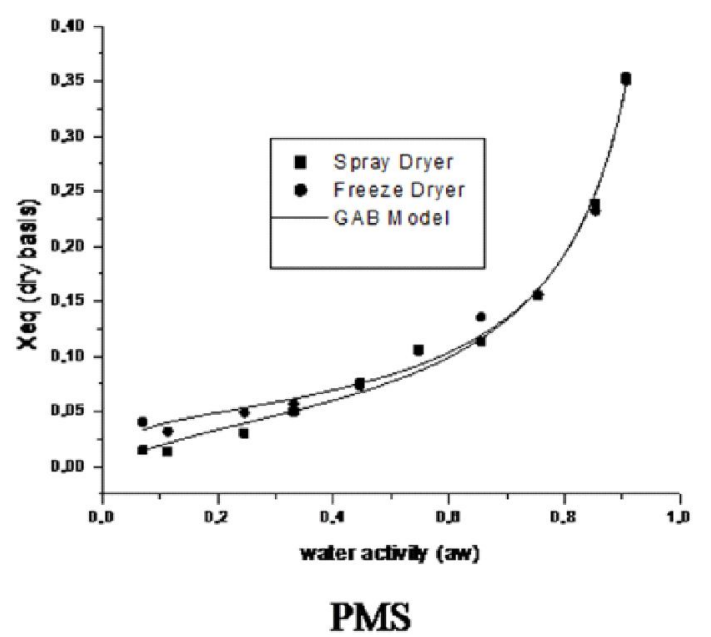

According to Comunian et al. (2011) the $\mathrm{X}_{\mathrm{m}}$ parameter (monolayer moisture content) corresponds to the amount of water strongly adsorbed to specific sites at the food surface and is considered a critical value above which the rate of some degradation reactions increase and the food matrix stability decreases. The Xm values obtained for spray dried and freeze dried passion juice varied from $4 \%$ to $6.4 \%$ and from $4 \%$ to $4.7 \%$, respectively, according to the GAB model, which are in agreement with the values obtained by Righetto and Netto (2005), Tonon et al. (2009) for spray dried acerola and açai powders, respectively, and with Moraga et al. (2006), for freeze-dried kiwi fruit.



Figure 3 - Influence of different drying methods on sorption isotherms of passion fruit pulp:maltodextrin:skimmed milk (PMS) and passion fruit pulp:gum arabic:skimmed milk (PGS) powder samples determined at $20^{\circ} \mathrm{C}$.

Table 1 - Estimated GAB parameters at 20,30,40 and 50 $\mathrm{C}$ for passion fruit pulp:maltodextrin:skimmed milk (PMS) and passion fruit pulp:gum arabic:skimmed milk (PGS) powders samples obtained by spray dryer and freeze dryer.

\begin{tabular}{cccccccccc}
\hline & Parameter & \multicolumn{4}{c}{ Spray Dryer } & \multicolumn{4}{c}{ Freeze Dryer } \\
\hline & & $20^{\circ} \mathrm{C}$ & $30^{\circ} \mathrm{C}$ & $40^{\circ} \mathrm{C}$ & $50^{\circ} \mathrm{C}$ & $20^{\circ} \mathrm{C}$ & $30^{\circ} \mathrm{C}$ & $40^{\circ} \mathrm{C}$ & $50^{\circ} \mathrm{C}$ \\
\hline \multirow{4}{*}{ PMS } & $\mathrm{C}$ & 5.38114 & 5.60037 & 2.42754 & 3.97874 & 31.59988 & 11.73934 & 3.31738 & 2.95084 \\
& $\mathrm{~K}$ & 0.95273 & 0.95253 & 0.84954 & 0.94814 & 0.96073 & 0.96307 & 0.87353 & 0.86925 \\
& $\mathrm{X}_{\mathrm{m}}$ (dry basis) & 0.04854 & 0.04616 & 0.06146 & 0.04084 & 0.04497 & 0.04256 & 0.05042 & 0.06488 \\
& $* \mathrm{CHI}^{2}$ & $1.0 \times 10^{-4}$ & $8.0 \times 10^{-5}$ & $1.0 \times 10^{-5}$ & $1.0 \times 10^{-5}$ & 0.00013 & 0.00006 & 0.00002 & 0.00005 \\
& $\mathrm{R}^{2}$ & 0.99313 & 0.99328 & 0.99843 & 0.998 & 0.99069 & 0.99492 & 0.99719 & 0.9936 \\
& $\mathrm{C}$ & 8.2491 & 7.23096 & 4.83757 & 4.23017 & 26.72869 & 7.74653 & 5.63981 & 7.4409 \\
& $\mathrm{KGS}$ & 0.95541 & 0.93301 & 0.94774 & 0.95303 & 0.97773 & 0.95486 & 0.9141 & 0.92174 \\
& $\mathrm{X}_{\mathrm{m}}($ dry basis) & 0.04763 & 0.04743 & 0.04208 & 0.04024 & 0.04289 & 0.04236 & 0.04782 & 0.0485 \\
& $\mathrm{CHI}^{2}$ & 0.00012 & 0.00003 & 0.00003 & 0.00002 & 0.00015 & 0.00007 & 0.00005 & 0.00003 \\
& $\mathrm{R}^{2}$ & 0.99174 & 0.99722 & 0.99632 & 0.99682 & 0.99064 & 0.99365 & 0.99381 & 0.9963 \\
\hline
\end{tabular}

$* \mathrm{CHI}^{2}=$ chi-square distribution $\left(C H I^{2}=\sum_{i=1}^{k} \frac{\left(O_{i}-E_{i}\right)^{2}}{E_{i}}\right)$, where: $\mathrm{O}=$ observed frequency; $\mathrm{E}=$ expected frequency. 
According to Pedro (2010), samples of passion fruit pulp with $18 \%$ maltodextrin $10 \mathrm{DE}$ showed values of Xm from 5.38 to $7.54 \%$, for samples with $55 \%$ maltodextrin DE 10 the range was from 6.1 to $6.5 \%$ which showed the smallest variation, and for those with passion fruit pulp and $18 \%$ of gum arabic the range was 8.05 to $6.31 \%$. Equation 2 predicts the increase in the $\mathrm{C}$ parameter with the decrease in temperature. For samples PGS and PMS obtained by spray and freeze drying, there was a tendency to this behavior. $K$ value represents a measure of the interactions between molecules of multilayers with the adsorbent. The values of $\mathrm{K}$ for the samples obtained by spray drying PMS were 0.84954 to 0.95273 and 0.93301 to 0.95541 PGS, while for lyophilized PMS and PGS they were 0.86925 to 0.96307 , and 0,91410 to 0.97773 , respectively. Similarly to this study, tests conducted by Pedro et al. (2010) showed that parameter $\mathrm{K}$ is little affected by type of additives and different temperatures.

The fitting of the isotherms with this model was high $(\mathrm{R}>0.99)$ and in all cases the results obtained in the present work for the adjustment of GAB model to the different powder samples are in accordance with the limit values for constants C and K suggested by Lewicki (1997), based on the mathematical analysis of the model (range $0.24<\mathrm{K}<1$ and $5.6<\mathrm{Cg}<\propto)$.

\section{Isosteric heat of sorption}

The dependence of isosteric heat of sorption on moisture content for PMS and PGS powders is shown in Figure 4, which illustrates a progressive increase in the heat of sorption in relation to decreasing moisture content. This may be due to the fact that during initial stages of sorption (low moisture content), there are highly active polar sites on the surface of the food material, which are covered with water molecules to form a monomolecular layer. This indicates greater water-solid interactions. As the water content increases, the covering of a less active sorption site and the formation of a multilayer is manifested by the decrease in heat of sorption (PÉREZ-ALONSO et al., 2006). In some moisture content values the isosteric heat of sorption corresponding to powders produced by spray drying were the highest. This suggests that the spray dried product has more surface polar sites than those of the products obtained by freeze drying. The elevated heat values of sorption of water under low moisture contents are an indication of strong water-food component interactions in the fruit.

We observed that the isosteric heat of the samples were all similar, comparing the relative equilibrium moisture content. The freeze dried PMS sample had a higher value of isosteric heat in the humidity of $0.025 \mathrm{~kg}$ water $/ \mathrm{kg}$ dry solid. After the value of $0.15 \mathrm{~kg}$ water $/ \mathrm{kg}$ dry solid isosteric heat of the samples were very similar.

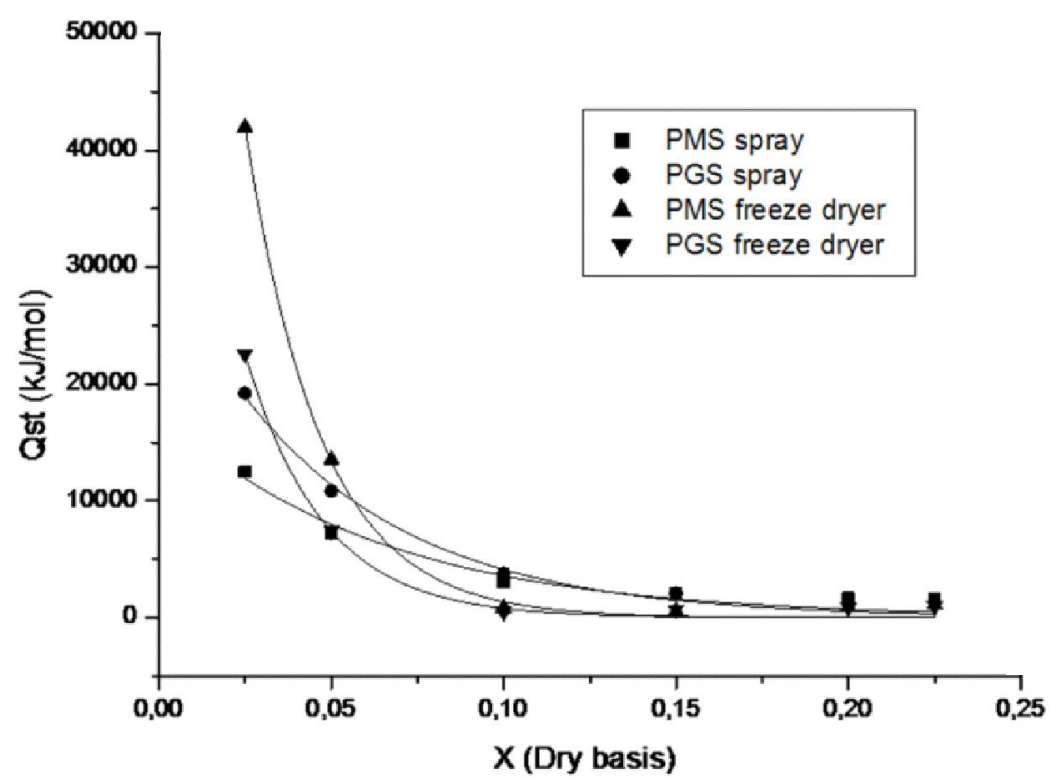

Figure 4 - Influence of drying methods and additives on the net isosteric heat of sorption process for passion fruit pulp:maltodextrin:skimmed milk (PMS) and passion fruit pulp:gum arabic:skimmed milk (PGS) powder samples. 


\section{CONCLUSION}

The sorption isotherms of the samples studies were type III, according to Brunauer's classification. There were small differences between the two drying methods used in relation to equilibrium moisture content, so it is possible to recommend to dehydration of passion pulp by spray drying, as it is a less expensive and faster method. The samples with maltodextrin and gum arabic had small differences in equilibrium moisture content, so it is possible to recommend ehydration of passion pulp using maltodextrin as an additive, since it is a less expensive and more available material. Samples of PMS and PGS in this study was observed in the presence of skimmed milk, which may be responsible for the slight difference in behavior in relation to other studies. However, one must consider the advantages associated with skimmed milk use, as not only is it cheaper and more easily accessible than other additives, it also adds nutritional value to the product as a source of protein, carbohydrate (lactose), vitamins and minerals. Due to the lowere price of maltodextrin compared to gum arabic and since their equilibrium moisture content values were very similar, it follows that the use of maltodextrin in the formulation seems to be more advantageous. We observed that a progressive increase in the heat of sorption in relation to decreasing moisture content and the values of different samples were all similar, comparing the relative equilibrium moisture content.

\section{ACKNOWLEDGEMENTS}

This work was supported by Fundação de Amparo à Pesquisa do Estado de São Paulo, FAPESP, (Process number: 2007/57712-1).

\section{REFERENCES}

ADHIKARI, B. et al. Effect of addition of maltodextrin on drying kinetics and stickiness of sugar and acid-rich foods during convective drying: experiments and modeling. Journal of Food Engineering, Amsterdam, v.62, n.1, p.53-68, 2004.

BHANDARI, B.R. et al. Spray drying of concentrated fruit juices. Drying Technology, New York, v. 11, n.5, p.1081-1092, 1993.

BRUNAUER, S. et al. On a theory of the van der Waals adsorption of gases. Journal of the American Chemical Society, Easton, v.62, n.1-24, p.1723-1732, 1940.

COLLARES, F.P.; KIECKBUSCH, T. G;; FINZER, J. R. D. A transição vítrea em produtos alimentícios. Brazilian
Journal of Food Technology, Campinas, v.5, n.5, p.117130, 2002.

COLLARES, F.P.; FINZER, J. R. D; KIECKBUSCH, T. G.

Glass transition control of the detachment of food pastes dried over glass plates. Journal of Food Engineering, Essex, v.61, n.2, p.261-267, 2004.

COMUNIAN, T.A. et al. Assessment of production efficiency, physicochemical propertiesand storage stability of spray-dried chlorophyllide, a natural food colourant, using gum Arabic, maltodextrin and soy protein isolate-based carrier systems. International Journal of Food Science and Technology, Oxford, v. 46, n.6, p.1259-1265, 2011.

GABAS, A.L. et al. Effect of maltodextrin and gum arabic in water vapor sorption thermodynamic properties of vacuum dried pineapple pulp powder. Journal of Food Engineering, Amsterdam, v.82, n.2, p.246-252, 2007.

GABAS, A. L.; MENEGALLI, F. C.; TELIS-

ROMERO, J. Water sorption enthalpy-entropy compensation based on isotherms of plum skin and pulp. Journal of Food Science, Chicago, v.65, n.4, p.680-684, 2000.

HUBINGER, M. et al. Water vapor adsorption isotherms of guava, mango and pineapple. Journal of Food Science, Chicago, v.57, n.6, p.1405-1407, 1992.

JOWITT, R. et al. Physical Properties of Foods. London and New York: Applied Science, 1983, 425p.

KUROZAWA, L.E.; PARK, K.J.; HUBINGER, D.M. Effect of maltodextrin and gum arabic on water sorption and glass transition temperature of spray dried chicken meat hydrolysate protein. Journal of Food Engineering, Amsterdam, v. 91, n.2, p. 287-296, 2009.

LANGRISH, T.A.G.; CHAN, W.C.; KOTA, K. Comparison of maltodextrin and skimmed milk wall deposition rates in a pilot-scale spray dryer. Powder Technology, Lousanne, v. 179, n. 1-2, p. 84-89, 2007.

LEWICKI, P. The applicability of the GAB model to food water sorption isotherms. International Journal of Food Science and Technology, Oxford, v.32,n.6, p.553-557, 1997. 
LOMAURO, C.J.; BAKSHI, A.S.; LABUZA, T.P.

Evaluation of food moisture isotherm equations. Part I: Fruit, vegetable and meat products. LebensmittelWissenschaft und- Technologie, London, v.18, p.111$117,1985$.

MARTINELLI, L.; GABAS, A. L.; TELIS-ROMERO, J. Thermodynamic and quality properties of lemon juice powder as affected by maltodextrin and gum arabic. Drying Technology, New York, v.25, n.12, p.2035-2045, 2007.

MCLAUGHLIN, C.P.; MAGEE, T.R.A. The determination of sorption isotherm and the isosteric heats of sorption for potatoes. Journal of Food Engineering, Amsterdam, v.35, n.3, p.267-280,1998.

MCNAMEE, B.F.; O'RIORDAN, E.D.; O'SULLIVAN, M. Emulsification and microencapsulation properties of gum arabic. Journal of Agricultural and Food Chemistry, Easton, v.46, n.11, p.4551-4555, 1998.

MORAGA, G.; MARTÍNEZ-NAVARRETE, N.; CHIRALT, A. Water sorption isotherms and phase transitions in kiwifruit. Journal of Food Engineering, Amsterdam, v. 72, n.2, p. 147-156. 2006.

PEDRO, M. A. M.; TELIS-ROMERO, J.; TELIS, V. R. N. Effect of drying method on the sorption isotherms and isosteric heat of passion fruit pulp powder. Ciência e Tecnologia de Alimentos, Campinas, v. 30, n.4, p.9931000, out-dez. 2010.

PÉREZ-ALONSO, C. et al. Thermodynamic analysis of the sorption isotherms of pure and blended carbohydrate polymers. Journal of Food Engineering, Amsterdam, v.77, n.4, p.753-760, 2006.

RAHMAN, S. Food Properties Handbook. Boca Raton: CRC Press, 1995.
REINECCIUS, G.A. Carbohydrates for flavor encapsulation. Food Technology, Chicago, v. 1, n.1, p. 144-146, 1991.

RIGHETTO, A.M.; NETTO, F.M. Effect of encapsulating materials on water sorption, glass transition and stability of juice from immature acerola. International Journal of Food Properties, New York, v.8, n.2, p.337-346, 2005.

RIZVI, S.S.H. Thermodynamic properties of foods in dehydration, In: M.A. RAO; S.S.H. RIZVI Engineering Properties of Foods. New York: Academic Press, 1995, $2^{\text {nd }}$, p.223-309.

SHAHIDI, F.; HAN, X.Q. Encapsulation of food ingredients. Critical Reviews in Food Science and Nutrition, Boca Raton, v. 33, n. 6, p.501-547, 1993.

SIRIPATRAWAN, U; JANTAWAT, P. Determination of moisture sorption isotherms of jasmine rice crackers using BET and GAB models. Food Science and Technology International, Madrid, v.6, n.12, p.459-465, 2006.

TELIS, V. R. N. et al. Water sorption thermodynamic properties applied to persimmon skin and pulp.

Thermochimica Acta, Amsterdam, v.343, n.1, p.49-56, 2000.

TONON, R.V. et al. Physicochemical and morphological characterisation of acai (Euterpe oleraceae Mart.) powder produced with different carrier agents. International Journal of Food Science and Technology, Oxford, v.44, n.10, p. 1950-1958, 2009.

VAN DEN BERG, C. Development of B.E.T. like models for sorption of water of foods; theory and relevance. In SIMATOS D.; MULTON J.L. Properties of water in foods. Dordrecht: Martinus Nijhoft Publishers. 1985, p. 119-135. 